\title{
Bioconversion of Municipal Solid Waste (MSW) and Water Hyacinth (WH) into Organic Manure by Fungal Consortium
}

\author{
Ayesha Parveen, A. (Corresponding author) \\ Department of Botany, Avinashilingam University for Women, Coimbatore - 641043, India \\ Tel: 91-98-4354-7960 E-mail: ayesha_n2001@hotmail.com \\ C. K. Padmaja \\ Department of Botany, Avinashilingam University for Women, Coimbatore - 641043, India \\ Tel: 91-99-4090-3181Ｅ-mail: padmaja_ckp@yahoo.com
}

\begin{abstract}
The present study was carried out to assess the degrading efficiency of the fungal consortium (Cellulolytic fungi Paecilomyces variotti and Chaetomium globosum, lignolytic fungi - Pleurotus florida and Tramates versicolor and actinomycetes - Streptomyces lavendulae and Thermobifida fusca ) in converting the Municipal solid waste (MSW) and Water hyacinth $(\mathrm{WH})$ mixture into an eco-friendly value added organic manure. The results revealed that the biomanure obtained by inoculation of fungal consortium into the municipal solid waste (MSW) and water hyacinth (WH) mixture was found to be efficient in enhancing the rate of decomposition within as they showed a drastic reduction in the biochemical parameters like organic carbon (21.09 per cent), cellulose (20.56 per cent), phenolic content $\left(0.46 \mathrm{mg} \mathrm{g}^{-1}\right)$ and reducing sugars $\left(0.67 \mathrm{mg} \mathrm{g}^{-1}\right)$. C: $\mathrm{N}$ ratio was narrowed down from 92:1 to $15: 1$, while nitrogen content increased from 0.37 percent to 1.39 per cent compared to uninoculated MSW-WH compost. $\beta$-glucosidase and urease enzyme activities were much pronounced upto 75 days from 0.05 to $2.82 \mathrm{Ul}^{-1}$ enzyme protein ( $\beta$-glucosidase) and from 0.93 to $2.39 \mu \mathrm{mol}$ of ammonia formed $\mathrm{mg}^{-1}$ enzyme protein (urease) in fungal consortium inoculated MSW-WH over the uninoculated MSW-WH compost.
\end{abstract}

Keywords: Municipal Solid Waste (MSW), Water Hyacinth (WH), Fungal consortium, Biomanure

\section{Introduction}

Coimbatore is an inland district in the Tamil Nadu state in India. The amount of municipal solid waste generated in Coimbatore city has been increased dramatically during the past several years. On an average, the city generates 800 metric tonnes per day of solid waste (Jayapriya and Saseetharan, 2007). Disposal of solid waste is by open dumping. A part of the waste is composted through a pit system. Coimbatore Municipal Corporation is now facing problems associated with solid waste management system.

The modern concept of environmental management is based on the recycling of waste. In this context, composting appears to be a safe form of treatment of some waste and the reclamation of the nutrients contained in them (Iranzo et al., 2004). During the last few years, composting has gained wide acceptance as a key component of integrated solid waste management. It has been promoted as an eco-friendly and sustainable solution to urban waste management. It encourages the production of beneficial microorganism (mainly the fungus) which in turn breaks down organic matter to create humus. Humus, a rich nutrient filled material, increase the nutrient content on soils and helps soil to retain moisture. Compost has also been shown to suppress plant diseases and pests and enhance higher yields of agricultural crops.

Water hyacinth, Eichhornia crassipes (Mart) Solms also known as 'blue devil', grows rapidly as a dense green mat over stagnant water bodies such as lakes, streams, ponds, waterways, ditches and backwaters. It is ranked as one of the world's worst invasive water weeds causing wide spread problems to millions of users of water bodies and water resources. It alters the ecosystem of the water body, causing oxygen fluctuation and raising the water temperature. There are many man-made lakes and ponds in Coimbatore district, which were once used to store water for domestic, irrigation and most importantly to promote ground water recharge. Most of these tanks and ponds receive invariably untreated sewage, untreated and partially treated effluent from local electroplating industries. Utilizing this potential 
water bodies, water hyacinth has grown enormously, which largely prefers nutrient-rich places for its sustenance. Fresh plant contains moisture - 92.8 per cent; ash content $417-\mathrm{g} \mathrm{kg}^{-1} ; \mathrm{pH}-8.1$; total organic carbon $-338 \mathrm{~g} \mathrm{~kg}^{-1}$; total nitrogen - $9.5 \mathrm{~g} \mathrm{~kg}^{-1}$; C:N ratio - 36:1; total potassium $9.7 \mathrm{~g} \mathrm{~kg}^{-1}$; phosphorus - $5.4 \mathrm{~g} \mathrm{~kg}^{-1}$; total-ferrous $-1640 \mathrm{mg} \mathrm{kg}^{-1}$; totalcopper $312 \mathrm{mg} \mathrm{kg}^{-1}$; total cadmium- $1.36 \mathrm{mg} \mathrm{kg}^{-1}$; total chromium- $41.18 \mathrm{mg} \mathrm{kg}^{-1}$; total lead- $67 \mathrm{mg} \mathrm{kg}^{-1}$ and total-Zn $640 \mathrm{mg} \mathrm{kg}^{-1}$. The weed rots in 15 days and it is an ideal component in fertilizers which makes the soil more fertile thereby enhancing better yield of crops. (Gupta et al., 2007).

Large amounts of compost prepared from municipal refuse are available. But most of these have low nitrogen and phosphorous content and are poor sources of nutrients for plant growth (Kapoor et al., 1983). One of the possible ways of increasing the nutrient content of the final compost product is microbial enrichment technique. This can be achieved either by introducing beneficial microorganisms by way of inoculation or by increasing the microbial activity by the incorporation of amendments (Rao and Tak, 2001). Inoculation of specific microflora during different stages of composting would hasten the decomposition potential that could imperatively yield good quality composts in shorter time spans (Taiwo and Oso, 2004).

Municipal solid waste is made up of different organic and inorganic fractions like food, vegetables, paper, wood, plastics, glass, metal and other inert material. Easily degradable fractions can be segregated from non-biodegradable fractions, suitably amended with water hyacinth and converted into nutrient enriched organic manure by microbial inoculants. The amendments not only influence soil fertility, but may also enhance the composition and activity of soil microorganisms. The overall goal of waste management is to collect, treat and dispose the waste using the most economical means available.

Hence, the present investigation was carried out to convert the municipal solid waste (MSW) and water hyacinth (WH) mixture into value added nutrient enriched organic manure by inoculating with the fungal consortium (Cellulolytic fungi - Paecilomyces variotti and Chaetomium globosum, lignolytic fungi - Pleurotus florida and Tramates versicolor and actinomycetes - Streptomyces lavendulae and Thermobifida fusca ) .

\section{Methodology}

Municipal solid waste was collected from Vellalore municipal corporation yard, Coimbatore. Water Hyacinth (WH) was collected from a pond in Kurichi, Coimbatore District. Cellulolytic fungi (Paecilomyces variotti and Chaetomium globosum), lignolytic fungi (Tramates versicolor) and actinomycetes (Streptomyces lavendulae and Thermobifida fusca) were bought from the Institute of Microbial Technology, Chandigarh, India. Lignolytic fungi (Pleurotus florida) was bought from Centre for Advanced studies in Agricultural Microbiology, Tamil Nadu Agricultural University, Coimbatore.

Paecilomyces variotti ( MTCC - 480), Chaetomium globosum (MTCC - 155) and Pleurotus florida were cultured in Potato Dextrose Agar Medium (PDA) ( $250 \mathrm{~g}$ of autoclaved potato, $20 \mathrm{~g}$ of dextrose and $15 \mathrm{~g}$ of agar in 1 litre of distilled water). Tramates versicolor (MTCC - 138) was cultured in yeast extract medium (5 g of yeast extract $10.0 \mathrm{~g}$ of glucose and $15 \mathrm{~g}$ of agar in 1 litre of distilled water). Streptomyces lavendulae (MTCC - *706) was cultured in malt and yeast extract medium $(3.0 \mathrm{~g}$ of malt extract, $3.0 \mathrm{~g}$ of yeast extract, $5.0 \mathrm{~g}$ of peptone, $10.0 \mathrm{~g}$ of glucose and $20.0 \mathrm{~g}$ of agar in 1 litre distilled water). Thermobifida fusca (MTCC - * 1754) was cultured in yeast extract and tryptone medium ( 3.0 $\mathrm{g}$ of tryptone, $3.0 \mathrm{~g}$ of yeast extract, $3.0 \mathrm{~g}$ of glucose, $1.0 \mathrm{~g}$ of dipotassium hydrogen phosphate and $20.0 \mathrm{~g}$ of agar in 1 litre distilled water). $1000 \mathrm{~g}$ of sterilized and dry MSW and WH was taken in the ratio 2:1 in a perforated thick gauge polythene bags. The polythene bags were marked and a mixture of fungal mass and actinomycetes were added to it, under aseptic conditions (approximately $100 \mathrm{~g}$ of microbial mass).

The rate of degradation of MSW - WH substrate mixture was determined at an interval of 15 days for 90 days by analyzing physical and biochemical parameters. The physical parameters analyzed were appearance, color, odor, $\mathrm{pH}$ and electrical conductivity. Appearance, color and odor were determined visually. The $\mathrm{pH}$ and Electrical conductivity were determined in 1:10 (w/v) waste/distilled water soluble extract using a $\mathrm{pH}$ meter and electrical conductivity meter in the Department of Botany, Avinashilingam University for Women, Coimbatore. Biochemical parameters determined were Cellulose (Updegroff, 1969), Organic Carbon (Walkely and Black, 1934), Total nitrogen (Microkjeldhal method Humphries, 1956), Phenol ( Folin Ciocalteau method - Bray and Thorpe, 1954), Reducing sugars ( Dinitrosalicylic acid method - Miller, 1972), $\beta$-glucosidase - filter paper activity (Sadasivam and Manikam,1996) and Urease (Nesslerization method -Sumner, 1955).

\section{Results and discussion}

\subsection{Physical parameters (Table -1)}

The mature compost in uninoculated MSW-WH mixture was dark brown in color, granular with wood earthy smell while in inoculated MSW-WH mixture; it was black in color, granular and fibrous with pleasant earthy smell compared to the raw MSW-WH mixture which was light brown in color, coarse in appearance with a foul smell. The appearance of black color is indicative of is maturity. Pandharipande et al. (2004) reported that the mature compost must be dark 
brown or black, granular, spongy in feel and smell normally. A significant decrease in $\mathrm{pH}$ and EC were observed in uninoculated MSW-WH compost which was 7.90 and $0.32 \mathrm{dSm}^{-1}$ and 6.83 and $0.28 \mathrm{dSm}^{-1}$ in fungal consortium inoculated MSW-WH compost over the raw MSW-WH $\left(8.28\right.$ and $\left.0.49 \mathrm{dSm}^{-1}\right)$ respectively. The occurrence of $\mathrm{pH} 6.83$ and EC $0.28 \mathrm{dSm}^{-1}$ in fungal consortium inoculated MSW-WH compost after 90 days of decomposition can be due to the bioconversion of organic materials into various intermediate types of organic acids and higher mineralization of the nitrogen and phosphorus into nitrites/nitrates and orthophosphates respectively. Jeevan Rao (2008) reported a pH of 7.9 and EC of $0.46 \mathrm{dSm}^{-1}$ in urban solid waste compost and showed a decrease with the advancement in period of composting from 30 to 120 days.

\subsection{Biochemical parameters (Table -2, 3, 4 and 5)}

The cellulose content in raw MSW-WH mixture was 56.68 per cent. It was decreased to 31.55 per cent in uninoculated MSW -WH compost and 20.56 per cent in fungal consortium inoculated sample. A significant decrease in cellulose content in fungal consortium inoculated MSW-WH after 90 days of decomposition might be attributed to the significant production of cellulase enzyme by microbes. The cell free enzymes are capable of completely hydrolyzing crystalline cellulose in vitro. Tamilarasi (2006) observed a decrease in cellulose content of kitchen waste from 34.71 per cent to 10.93 per cent $(\mathrm{P}<0.01)$ after 60 days of decomposition with activated Effective microorganism treatment. Padmaja and Sangeeth (2008) also reported a decrease in the cellulose content of Municipal Solid Waste (MSW) from 34.71 per cent 10.93 per cent with Effective Microorganism treatment.

The Organic carbon (OC) and Organic matter (OM) of raw MSW -WH mixture were 34.07 per cent and 58.73 per cent and after 90 days decomposition, it was decreased drastically to 24.45 per cent and 39.91 per cent in uninoculated MSW-WH and to 21.09 per cent and 36.36 per cent in fungal consortium inoculated sample. The reduction in Organic carbon and Organic matter in fungal consortium inoculated MSW- WH decomposed sample might be due to higher mineralization of organic matter by micro flora. Jilani (2007) reported a decrease in organic carbon and organic matter from 33.0 per cent to 23.0 per cent $(\mathrm{OC})$ and from 57.0 per cent to 39.65 per cent (OM) respectively in windrow method of composting municipal solid waste of Karachi city. A significant increase of 1.39 per cent in total nitrogen content was noticed in fungal constortium inoculated MSW-WH compost than the uninoculated MSW -WH compost (1.03 per cent) after 90 days decomposition. The apparent increase in total nitrogen content in the biocompost is not only due to enhancement of nutrient but also due to reduction in weight because of decomposition. Padmaja and Sangeeth (2008) obtained an increased total nitrogen content of 1.23 per cent from 0.57 per cent in Effective Microorganism inoculated solid waste compost (after 60 days). $\mathrm{C}: \mathrm{N}$ ratio has been used as an indication of the potential of compost maturity. C: $\mathrm{N}$ ratio of the raw MSW-WH mixture was 92:1 and it was narrowed down drastically to 24:1 in uninoculated compost and to $15: 1$ in fungal consortium inoculated compost after 90 days of decompostition. Indeed, the decrease of the $\mathrm{C} / \mathrm{N}$ ratio is explained by the transformation of carbon into carbon dioxide followed by a lower decrease in the concentration of organic acids (Chefetz et al .1998). Jeevan Rao (2008) observed a significant reduction in C: N ratio from 43:1 to 17: 1 in Pleurotus sajor caju inoculated urban solid waste.

The total phenolic content in raw MSW-WH waste was $2.73 \mathrm{mg} \mathrm{g}^{-1}$. A marked reduction in total phenolic content of $0.71 \mathrm{mg} \mathrm{g}^{-1}$ in uninoculated compost and $0.46 \mathrm{mg} \mathrm{g}^{-1}$ in fungal consortium inoculated MSW-WH compost was recorded after 90 days of decomposition. A Significant reduction in total phenolic content in fungal consortium inoculated MSW-WH sample might be due to metabolic activity of cellulolytic, lignolytic and actionmycetous organisms and is indicative of the antitoxicity effect of the compost for application to agricultural crops. Padmaja and Sangeeth (2008) during their study on the recycling of solid waste into organic manure by EM (Effective Microorganism), observed a reduction in the total phenolic content in EM-SW compost from $1.50 \mathrm{mg} \mathrm{g}^{-1}$ to $0.67 \mathrm{mg} \mathrm{g}^{-1}$ after 60 days of decomposition.

The reducing sugar content in raw MSW-WH mixture was $2.37 \mathrm{mg} \mathrm{g}^{-1}$ and it was decreased significantly to $0.80 \mathrm{mg} \mathrm{g}^{-1}$ in uninoculated MSW-WH compost and $0.67 \mathrm{mg} \mathrm{g}^{-1}$ in fungal consortium inoculated compost after 90 days of decomposition. Reduction in reducing sugars content in fungal consortium inoculated MSW-WH sample might be due to the action of microorganisms that par take in the degradation process which utilize sugar as their carbon source. Padmaja and Sangeeth (2008) also obtained a remarkable reduction in reducing sugar during the decomposition of solid waste by Effective Microorganisms.

$\beta$-glucosidase activity was very much pronounced $\left(2.82 \mathrm{IU} \mathrm{mg}^{-1}\right)$ in fungal consortium inoculated MSW- WH compost than the uninoculated MSW-WH compost (0.92 $\left.\mathrm{IU} \mathrm{mg}^{-1}\right)$ upto 75 days and declined to 1.69 and 0.72 $\mathrm{IU} \mathrm{mg} \mathrm{m}^{-1}$ over 90 days of degradation. The least $\beta$-glucosidase activity was registered in raw MSW-WH mixture $(0.05 \mathrm{IU}$ $\mathrm{mg}^{-1}$ ). Imanuel et al. (2006) also obtained a high level of $\beta$-glucosidase enzyme production of $0.34 \mathrm{IU} \mathrm{m}^{-1}$ and $29 \mathrm{IU}$ $\mathrm{ml}^{-1}$ by Aspergillus fumigatus and A.niger fermented coir waste and saw dust.

A significant increase in urease activity of $1.32 \mu \mathrm{mol}$ of Ammonia formed $\mathrm{min}^{-1} \mathrm{mg}^{-1}$ enzyme protein was recorded in uninoculated MSW-WH compost and of $2.39 \mu$ mol of Ammonia formed $\mathrm{min}^{-1} \mathrm{mg}^{-1}$ enzyme protein in fungal consortium inoculated MSW-WH samples upto 75 days and gradually declined to 1.26 and $1.89 \mu$ mol of Ammonia 
formed $\min ^{-1} \mathrm{mg}^{-1}$ enzyme protein . Fungal consortium inoculated MSW-WH mixture showed much pronounced urease enzyme activity and it might be attributed to the production of ammonia and also due to the progressive utilization of organic acids by microbial population present in the decomposed product. Chang et al. (2007) during their study on different application rates of compost, observed that the populations of bacteria, fungi and actinomycetes as well as soil enzyme activities like urease and phosphotases increased significantly in the compost treated soils compared to chemical fertilizer treated soil.

\section{Conclusion}

Thus, it can be deduced from the present findings that the waste, municipal solid waste and water hyacinth can be effectively harnessed by microorganisms as cost effective, value added nutrient enriched organic manure. By this waste management technology, waste disposal and fertilizer usage costs can be reduced.

\section{References}

Bray, H.G. and. Thorpe, W.V. (1954). Analysis of phenolic compounds of interest in metabolism. Meth. Biochem. Anal, 1: $27-52$.

Chang, E.H., Chung, R.S. and Tsai, Y.H. (2007). Effect of different application rates of organic fertilizer on soil enzyme activity and microbial population, Soil Sci. and Pl. Nu., 53 (2): 132-140.

Chefetz, B., Hatcher ,P.G., Hadar, Y and Chen Y. (1998). Characterization of Dissolved Organic Matter Extracted from Composted Municipal Solid Waste. Soil Sci. Soc.Am. J., 62: 326-332.

Gupta, R., Mutiyar, P.K., Rawat, N.K., Saini, M.S and Garg, V.K. (2007). Development of a water hyacinth based vermireactor using an epigeic earthworm Eisenia foetida. Bioresour. Technol., 98: 2605-2610.

Humphries, E.C. (1956). Mineral composition and ash analysis. p. 468-502. In: K. paech and M.V. Tracey (Eds). Modern methods of plant analysis, 1, Springer Verlag, Berlin.

Immanuel, G., Dhanusa, R., Prema, P and Palavesam, A. (2006). Effect of different growth parameters on endoglucanase enzyme activity by bacteria isolated from coir retting effluents of estuarine environment. Int. J. Environ.Sci.Tech, 3 (1):25-34.

Iranzo, M., Canizares, J.V., Perez, L.R., Pardo, I.S., Mormeneo, S. and Boluda R. (2004). Characteristics of rice straw and sewage sludge as composting material in Valencia (Spain). Bioresour. Technol., 95: 107-112.

Jeevan Rao, K., Rama Lakshmi, Ch.S. and Sreenivasa Raju, A. (2007). Evaluation of Manurial value in Urban and Agricultural Waste Composts. J.Indian Soc.Soil Sci, 56(3):295-299.

Jeyapriya, S.P. and Saseetharan, M.K. (2007). Study on municipal solid waste refuse characteristic and leachate samples of Coimbatore city. Nature Environ. Poll. Techn, 6: 149-152.

Jilani, S. (2007). Municipal Solid Waste composting and its assessment for reuse in plant production. Pak. J. Bot, 39(1):271-277.

Kapoor, K.K., Yadav, K.S., Singh, D.P., Mishra, M.M. and Tauro, P. (1983). Enrichment of compost by Azotobacter and phosphate solubilizing microorganisms. Agric Wastes, 5: 125 - 133.

Miller, G.L. (1959). Use of dinitrosalicylic reagent for determination of reducing sugar. Anal. Chem, 31:426 - 428.

Padmaja, C.K. and Adelene Sanseeth, D. (2008). Recycling of solid waste in to organic manure by EM (effective microorganism) technology. Ad. Plant Sci, 21(11): 585-586.

Pandharipande, S.L., Gadekar, S. and Agrawal, R. (2004). Bio conservation of press mud (a waste from sugar industry). Asian .Jr .of Microbiol. Biotech. Env, 6 (1): 87-88.

Rao, A.V and Tak, R. (2001). Effect of rhizobial inoculation on Albizia lebbeck and its rhizosphere activity in mine spoils. Arid Land Res. Manage, 15: 157-162.

Sadasivam, S. and Manickam, A. (1996). Biochemical methods, Newage Internationa (P) Ltd., Publishers, $2^{\text {nd }}$ Edn.

Sumner, J.B. (1955). Estimation of urease. In: Methods in Enzymology (eds.) Chowick, S.P. and Kaplan, 2: 378-379.

Taiwo, L.B and Oso, B.A. (2004). Influence of composting techniques on microbial succession, temperature and $\mathrm{pH}$ in a composting municipal solid waste. African.J. Biotechnol, 3: 239-243.

Tamilarasi, A. (2006). Recycling of kitchen waste into organic manure by Effective Micro-organisms (EM) and its effect on Vigna unguiculata (L.) walp. M.Sc. Thesis. Avinashilingam University, Coimbatore.

Updegraff, D.M. (1969). Semi - micro determination of cellulose in biological materials. Ann. Biochem, 32: 420 - 444.

Walkely, A. and Black, C.A. (1934). An examination of the Degtiareff method for determining organic matter and proposed modification of chromic acid titration method. Soil Sci, 37:29-38. 
Table 1. Changes in physical parameters of raw and composted MSW -WH

\begin{tabular}{|l|l|l|l|}
\hline \multirow{2}{*}{ Parameters } & \multirow{2}{*}{ Initial (Raw) } & \multicolumn{2}{|c|}{ Composted } \\
\cline { 3 - 4 } & & Control (uninoculated) & Fungal consortium (inoculated) \\
\hline Color & Light brown & Dark brown & Black \\
\hline Appearance & Coarse & Granular & Granular and fibrous \\
\hline Odor & Foul smell & Wood earthy smell & Earthy smell \\
\hline pH & 8.28 & 7.90 & 6.83 \\
\hline EC $\left(\mathrm{dSm}^{-1}\right)$ & 0.49 & 0.32 & 0.28 \\
\hline
\end{tabular}

Table 2. Changes in biochemical parameters of raw and composted MSW - WH

\begin{tabular}{|c|c|c|c|c|c|c|}
\hline \multirow{2}{*}{$\begin{array}{c}\text { Days of } \\
\text { observation }\end{array}$} & \multicolumn{2}{|c|}{$\begin{array}{l}\text { Cellulose } \\
\text { (in per cent) }\end{array}$} & \multicolumn{2}{|c|}{$\begin{array}{l}\text { Organic carbon } \\
\text { (in per cent) }\end{array}$} & \multicolumn{2}{|c|}{$\begin{array}{l}\text { Organic matter } \\
\text { (in per cent) }\end{array}$} \\
\hline & $\begin{array}{c}\text { Control } \\
\text { (uninoculated) }\end{array}$ & $\begin{array}{c}\text { Fungal } \\
\text { consortium } \\
\text { (inoculated) }\end{array}$ & $\begin{array}{c}\text { Control } \\
\text { (uninoculated) }\end{array}$ & $\begin{array}{c}\text { Fungal } \\
\text { consortium } \\
\text { (inoculated)) }\end{array}$ & $\begin{array}{c}\text { Control } \\
\text { (uninoculated) }\end{array}$ & $\begin{array}{c}\text { Fungal } \\
\text { consortium } \\
\text { (inoculated) }\end{array}$ \\
\hline Initial (raw) & \multicolumn{2}{|c|}{56.68} & \multicolumn{2}{|c|}{34.07} & \multicolumn{2}{|c|}{58.73} \\
\hline 15 & 48.94 & 48.37 & 32.88 & 29.48 & 56.69 & 51.43 \\
\hline 30 & 43.82 & 40.56 & 29.28 & 26.96 & 50.48 & 46.48 \\
\hline 45 & 41.39 & 34.45 & 28.15 & 25.08 & 48.53 & 43.24 \\
\hline 60 & 38.15 & 30.50 & 26.28 & 23.74 & 45.31 & 40.93 \\
\hline 75 & 34.22 & 28.00 & 25.43 & 22.46 & 41.42 & 38.72 \\
\hline 90 & 31.55 & 20.56 & 24.45 & 21.09 & 39.91 & 36.36 \\
\hline SED & \multicolumn{2}{|c|}{0.62} & \multicolumn{2}{|c|}{0.52} & \multicolumn{2}{|c|}{0.90} \\
\hline $\mathrm{CD}(\mathrm{P}<0.01)$ & \multicolumn{2}{|c|}{1.71} & \multicolumn{2}{|c|}{1.46} & \multicolumn{2}{|c|}{2.52} \\
\hline
\end{tabular}


Table 3. Changes in biochemical parameters of raw and composted MSW - WH

\begin{tabular}{|c|c|c|c|c|}
\hline \multirow[b]{2}{*}{$\begin{array}{c}\text { Days of } \\
\text { observation }\end{array}$} & \multicolumn{2}{|c|}{ Total nitrogen content (in per cent) } & \multicolumn{2}{|c|}{$\mathrm{C}: \mathrm{N}$ ratio } \\
\hline & $\begin{array}{c}\text { Control } \\
\text { (uninoculated) }\end{array}$ & $\begin{array}{c}\text { Fungal } \\
\text { consortium } \\
\text { (inoculated)) }\end{array}$ & $\begin{array}{c}\text { Control } \\
\text { (uninoculated) }\end{array}$ & $\begin{array}{c}\text { Fungal } \\
\text { consortium } \\
\text { (inoculated)) }\end{array}$ \\
\hline Initial (raw) & \multicolumn{2}{|c|}{0.37} & \multicolumn{2}{|c|}{$92: 1$} \\
\hline 15 & 0.53 & 0.64 & $62: 1$ & $56: 1$ \\
\hline 30 & 0.64 & 0.86 & $46: 1$ & $31: 1$ \\
\hline 45 & 0.72 & 0.99 & $39: 1$ & $25: 1$ \\
\hline 60 & 0.81 & 1.04 & $32: 1$ & $23: 1$ \\
\hline 75 & 0.93 & 1.21 & $27: 1$ & $19: 1$ \\
\hline 90 & 1.03 & 1.39 & $24: 1$ & $15: 1$ \\
\hline SED & & & & \\
\hline $\mathrm{CD}(\mathrm{P}<0.01)$ & & & & \\
\hline
\end{tabular}

Table 4. Changes in biochemical parameters of Raw and composted MSW- WH

\begin{tabular}{|c|c|c|c|c|}
\hline \multirow[t]{2}{*}{$\begin{array}{c}\text { Days of } \\
\text { observation }\end{array}$} & \multicolumn{2}{|c|}{$\begin{array}{l}\text { Total phenolic content } \\
\qquad\left(\mathrm{mg} \mathrm{g}^{-1}\right)\end{array}$} & \multicolumn{2}{|c|}{$\begin{array}{l}\text { Reducing sugars } \\
\qquad\left(\mathrm{mg} \mathrm{g}^{-1}\right)\end{array}$} \\
\hline & $\begin{array}{c}\text { Control } \\
\text { (uninoculated) }\end{array}$ & $\begin{array}{c}\text { Fungal } \\
\text { consortium } \\
\text { (inoculated) }\end{array}$ & $\begin{array}{c}\text { Control } \\
\text { (uninoculated) }\end{array}$ & $\begin{array}{c}\text { Fungal } \\
\text { consortium } \\
\text { (inoculated)) }\end{array}$ \\
\hline Initial (raw) & \multicolumn{2}{|c|}{2.73} & \multicolumn{2}{|c|}{2.37} \\
\hline 15 & 2.48 & 2.02 & 1.42 & 1.92 \\
\hline 30 & 2.17 & 1.83 & 1.30 & 1.81 \\
\hline 45 & 1.69 & 1.19 & 1.22 & 1.49 \\
\hline 60 & 1.47 & 1.00 & 0.92 & 1.33 \\
\hline 75 & 0.92 & 0.73 & 0.83 & 1.03 \\
\hline 90 & 0.71 & 0.46 & 0.80 & 0.67 \\
\hline SED & \multicolumn{2}{|c|}{0.07} & \multicolumn{2}{|c|}{0.04} \\
\hline $\mathrm{CD}(\mathrm{P}<0.01)$ & \multicolumn{2}{|c|}{0.20} & \multicolumn{2}{|c|}{0.11} \\
\hline
\end{tabular}


Table 5. Changes in enzyme activity of raw and composted MSW-WH

\begin{tabular}{|c|c|c|c|c|}
\hline \multirow{2}{*}{$\begin{array}{c}\text { Days of } \\
\text { observation }\end{array}$} & \multicolumn{2}{|c|}{$\beta$-glucosidase* } & \multicolumn{2}{|c|}{ Urease** } \\
\hline & $\begin{array}{c}\text { Control } \\
\text { (uninoculated) }\end{array}$ & $\begin{array}{c}\text { Fungal } \\
\text { consortium } \\
\text { (inoculated) }\end{array}$ & $\begin{array}{c}\text { Control } \\
\text { (uninoculated) }\end{array}$ & $\begin{array}{c}\text { Fungal } \\
\text { consortium } \\
\text { (inoculated) }\end{array}$ \\
\hline Initial (raw) & \multicolumn{2}{|c|}{0.05} & \multicolumn{2}{|c|}{0.93} \\
\hline 15 & 0.12 & 0.30 & 0.32 & 0.52 \\
\hline 30 & 0.20 & 0.54 & 0.48 & 0.71 \\
\hline 45 & 0.38 & 0.72 & 0.55 & 0.89 \\
\hline 60 & 0.52 & 0.99 & 1.12 & 1.31 \\
\hline 75 & 0.92 & 2.82 & 1.32 & 2.39 \\
\hline 90 & 0.72 & 1.69 & 1.26 & 1.89 \\
\hline SED & \multicolumn{2}{|c|}{0.04} & \multicolumn{2}{|c|}{0.05} \\
\hline $\mathrm{CD}(\mathrm{P}<0.01)$ & \multicolumn{2}{|c|}{0.11} & \multicolumn{2}{|c|}{0.14} \\
\hline
\end{tabular}

* Enzyme activity expressed in $\mathrm{Ul}^{-1} \mathrm{mg}^{-1}$ enzyme protein

** Enzyme activity expressed in ( $\mu$ mol of ammonia formed $\mathrm{mg}^{-1}$ enzyme protein) 